Journal of Social Sciences 4 (4): 334-337, 2008

ISSN 1549-3652

(C) 2008 Science Publications

\title{
Environment Changes of Lampao Dam Communities in Northeast Thailand
}

\author{
${ }^{1}$ Winyoo Sata, ${ }^{1}$ Vinai Veravatnanond, ${ }^{2}$ Pairoj Bowjai and ${ }^{3}$ Prasopsuk Rithdet \\ ${ }^{1}$ Faculty of Environment and Resource Studies, \\ Mahasarakham University, Thailand, 44150 \\ ${ }^{2}$ Chandrakasem Rajabhat University, Thailand, 10900 \\ ${ }^{3}$ Faculty of Humanities and Social Sciences, \\ Rajabhat Mahasarakham University, Thailand, 44000
}

\begin{abstract}
Problem statement: The objective of this research was to study the environment change of Lampao Dam communities in Northeast Thailand, being a case study of the Sa-Adnathom community, Lamklong sub-district, Muang, Kalasin province, adjacent to the Lampao Dam. Approach: A qualitative research, it started with a review of literature and related researches. Field data were collected by way of interviews and both participant and non-participant observations, involving 15 informants including senior-villagers, who had lived in the village some 10-20 years. The research data were descriptively analyzed and presented. Results: As a result its was found that the Lampao Dam communities date back 200 years to the era of Chiangsom Kingdom. Deserted due to deadly epidemics, the area was later on repopulated by migrants from Yang Talad district, Kalasin province. A new community, called Sa-Adnathom, was born. Prior to the inception of the National Plan for Social and Economic Development in 1961, the environment of this community was complete with fertile land and natural resource abundance. People lived in harmony with nature and relied on resources from it for their livelihood, especially from Nong Waeng reservoir, Phan and Yang streams and Khoke Ngoo forest. But with the implementation of the first Plan for Social and Economic Development in 1961-1966 the Thai government started the construction of the Lampao Dam in 1963. Completed in 1968, the Dam took land from the villagers, part of which were simply flooded. This forced the village farmers to change their means of livelihood from relying on forest and rivers to production methods which by necessity involved purchase of machines and usage of chemical fertilizers. In short, a change from farming to fishing in Lampao Dam. Their values also changed from local exchanges of goods to money economy, which only led to household debts, increasing with rising degree of consumerism. Eventually people in the community realized the problems. Together they turned around, changing the direction of their development from money-oriented economy back to environment rehabilitation in the community. Starting in 1997 they adopted the King's philosophy of Sufficiency Economy. This concept of development did help to revive the environment of SaAdnathom community-their farm land, natural water resource and forest. They engaged in organic farming, reduced mono-crop growing and returned to reliance on natural means to meet their four basic needs in life. Conclusion: This research yielded a recommendation regarding policy guidelines for community development in Thailand. That is, the environment impact on the adjacent community of the dam should be given a careful consideration before such a project would be launched.
\end{abstract}

Key words: Environment change, lampao dam community

\section{INTRODUCTION}

The changes of the world environment in the last 200 years have taken place rapidly. The exploitation or the removal of natural resources from their origins has led to the extinction of many species of plants and animals. The widespread poisoning of the atmosphere, water and the seas has brought about global warming. The change in direction of water flows on the earth surface and the melting of the polar ice have affected seasonal changes as well as such natural occurrence as earth quakes, volcano explosions, forest fires, floods, droughts and the red color of sea water. All these changes have unavoidably impacted living things

Corresponding Author: W. Sata, Faculty of Environment and Resource Studies, Mahasarakham University, Mahasarakham, Thailand, 44150 Tel: +66-43-742135 Fax: +66-43-742135 
especially human being. All the while during this same 200 years period, the rapid increase of world population and the deterioration of natural resources have forced the humans to reexamine their own activities such as their economic development of all kinds, technological development, knowledge transfers, education and conservation of community environment. Otherwise, disaster will inevitably happen to the earth and the humans as a whole ${ }^{[1]}$. In the same vein, the Saadnathom village community, adjacent to the Lampao Dam in Northeast Thailand, has faced the same rapid changes of their environment during the last few decades. This article presents a summary of the research on the environment changes of this community before and after the construction of the Lampao Dam.

History: The Settlement of sa-adnathom community: About 200 years ago, the Sa-adnathom community was born by settlement of people who migrated from the Lao-Thai Kingdom of the White Elephants. Archeological proofs may be seen from canals and the ponds surrounding the area, such as Nongwaeng and the old canals surrounding the city of Chiangsom. Thus Sa-adnathom must have been an agricultural community, relying on natural resources for their livelihood. Besides, Sa-adnathom was also a commercial centre trading in cattle with Nongwaeng Swamp in the east as the encampment site for traders from surrounding villages. Later on these settlers of Chiangsom deserted the community. Sa-adnathom folks related their common hypothesis: "This area used to be a deserted village. Deadly epidemics or some kind of war forced people to move away. Repeated droughts and floods must have also caused famine. So people moved away and sought new place to make their living". In 1892 a group of Thai-Lao people migrated from Kham Makmai village, Yangtalad district, Kalasin to occupy this deserted area. During the reign of Rama VII, the revolution in 1932 brought about a new regime along with governmental reforms such as restructuring of some districts and provinces. Yangtalad district came under direct jurisdiction of Nakorn Rajsima Subregion. An epidemics broke out in Yangtalad district, causing villagers of Kham Makmai, Khambon and Nongkhon to come together and seek new homes. They set out along the Yang river on the south of Yangtalad district and settled down near Nongwaeng, a basin suitable for agriculture. Adjacent to Nongwaeng was Khoke Ngoo, a very rich forest, also near Yang river. By 1953, there were merely 10-15 households in this new settlement. They moved further to the Yang river basin, settling down close to Phan river basin (which was later known as Pao river). Originated in Udon
Thani, the Pao river merges with the Yang river at Lamklong sub-district, Muang district, Kalasin. Saadnathom village belongs to this sub-district.

Sa-adnathom ways of life before lampao dam: Community ways of life in the Lampao basin were quite abundant. The number of households and the population increased. The environment, the community's natural capital, during 1953-1962 was rich with biological diversity--the Khoke Ngoo forest, natural water resources and Yang river. The Nongwaeng community land included both river basin and high lands. All these rich natural resources were more than enough for the people residing there in $\mathrm{Sa}-$ adnathom community during the period from 18921963. There were not so many people either, due to limited communication with the outside world. Travels then had to rely on foot, ox-carts, horsebacks or boats ${ }^{[2]}$. The water for agriculture on the Lampao riversides solely depended on rain. Thus in same years it was flooded and in other years it was drought causing famine. In such event many residents migrated to big provinces in all parts of Thailand. Meanwhile the Thai government began to implement the first national economic development plan (1961-1966) in order to prevent flood as well as to utilize the Lampao water for agriculture. This led to the Lampao Dam Project, which started construction in 1963 and completed in 1968. The Dam caused significant changes both in the environment and community ways of life in its vicinity.

Community ways of life changed during construction 1963-1968: The construction of Lampao Dam led to the community's loss of their community land. Forest areas were widely destroyed. About 4,000 households lost their farmland with little compensation, 110 baht per rai, hardly enough to buy new plots. And it was delayed until 1965 when the villagers received their money. Only 10 percent of the households could still hold on to their lands and remained to live along the curvy rims of the Dam. During the Dam construction drastic changes took place, affecting community ways of life. Some people changed from farming to fishing; while those who grew vegetables did so for commercial purposes ${ }^{[3]}$, exploiting the high lands and utilizing the Dam water. Income increase attracted people from nearly provinces to the area. Land became more expensive. But still people migrated there to make fishing as their occupation. At the same time they could do other things to earn. Besides, tourism added to their income. Towards the end of 1968, the Provincial Electricity Authority introduced high-power connection into the Lampao Dam area, causing lots of 
grown trees to be cut down. The community became barren, no woods for neither shades nor fire. People began to change from wooden fire cooking to electric utensils. Radio and electric fans came along. Use of electricity became a new way of life.

Sa-adnathom community after dam construction, 1969-2001: After the completion of the Dam the Saadnathom villagers continued to live along the high earth dikes surrounding the Dam, less than 25 meters away from the main dike. Yet they could not make use of the Dam water for consumption. They have to fetch water from a single well some 3 kilometers away. They can use the Dam water for fishing only. However, when the water level receded, they could plant vegetables for a short period of time, such as beans, Bombay hemp, watermelon and small cucumber. It can be seen that the ways of life of Sa-adnathom villagers have been radically changed. Changes in production means and ways to make their living have also changed the environment. Public utilities system, communication with outside world roads, electricity and other basic structures came into being. People in the community see the Lampao Dam as a big farmland on which they can earn more income both from fishing and tourism. They have come to depend on the market and lesser reliance on natural environment. Technology for production, investment for production equipments and more use of chemical fertilizers have deteriorated their health. More income but higher expenditure ${ }^{[4]}$. These changes in community ways of life took place slowly at the beginning but more and more rapidly in later stages. But it all took place because of the push by the power and policy of the state with the intention to create the consumerist system of economy. The consumerist community ways to produce for sale have made people careless about their own life and families. During 1969-1979 destruction of natural resources and the ecological system as well as community health commenced. Market-oriented culture and dependence on government and others began to take root. People began to retreat from traditional ways of community life. During 1980-1990 the Lampao Dam community environment was more seriously destroyed. Having adopted the consumerist ways, the ecological system was incessantly destroyed; the fertile land was contaminated with poisonous chemical substance and insecticides damaging the productive quality of land. Thus people turned to chemical fertilizers. More and more poisonous chemical substance flowed into the water, harming both animals and people that consumed water from both Yang river and Nongwaeng. During 1991-2001 use of technology for production increase intensified, leading to even more violent damages of land, water, air and the environment.

Sa-adnathom community sought alternative way to rehabilitate the environment, 2002-2008: Faced with such problems as deterioration of the environment and natural resources, the Sa-adnathom villagers sought alternative way to revive the environment back to its wholeness. They organized a study group to learn production strategies which would not destroy the environment such as organic agriculture, adopting sufficiency ways of living, decreasing the use of chemical substance in planting. A group of NGOs and academics came in to assist them with self-reliant agriculture, to lessen dependence on market and machines and to turn back to live more with nature. Such efforts were not enough to withstand the societal trends because the villagers had already sunken deep in the luxurious culture from outside. Nevertheless most people of Sa-adnathom held fast in their belief that they would be able to rehabilitate natural resources and the environment. They would not give up.

Sa-adnathom villagers' greening of lampao dam communities: The people of Sa-adnathom community are Buddhists. They have lived their life in relation with the Buddhist temple since the beginning of the village. Therefore, they have turned to the Buddhist teaching of sufficiency way of life as conceptual framework for community culture $^{[5]}$. This concept jives with the new theory on "Sufficiency Economy" advocated by His Majesty the King of Thailand. Applying this philosophy as their principle for environmental rehabilitation, the Sa-adnathom villagers have begun to organize alternative occupation groups, emphasizing sufficiency economy such as organic agriculture, organic fertilizers, fermented fertilizers and trees planting on the highlands and along the dikes around the Dam, rehabilitating water resources, trying to maintain the natural balance. At the same time they reduce mono-crops while engaging inmixed agriculture. Slowly they have succeeded in the greening of the area. Together they have started a common learning process on the conservation of nature and the environment. Never again would they allow their environment to deteriorate.

\section{CONCLUSION}

The environment changes in Lampao Dam communities in Northeast Thailand interrelate with the historical development and the ecological system of the communities as well as with the relations of people and 
production technology. When capitalist economy entered the agricultural society of Sa-adnathom community by way of state policy through the construction of Lampao Dam and other social organization, linking Lampao Dam communities with national capitalist economy, changes took place in the environment, values and beliefs of that communitymoving towards a new system of economy. But the community realized that such changes were bringing about disaster; social organizations were found to solve the problems, change production structures and to rehabilitate the environment. To achieve such goals social and cultural capital from old days were called upon to integrate with the concept of Sufficiency Economy, which corresponds to traditional Isan Buddhist teaching ${ }^{[6]}$.

The main recommendation from this study is this: The process which brought about the environment changes to the Lampao Dam communities was imposed from outside by the state without participation on the part of the community. Nor were they given time to prepare for the changes. Therefore, central state authorities should seek community participation in the formulation of policy which will affect the environment and the ways of life of the community concerned before any action can be taken.

\section{ACKNOWLEDGEMENT}

The researchers express their sincere appreciation for all of support provided and the referees for their helpful comments.

\section{REFERENCES}

1. Vinai Veeravatnanond, 1998. Environment and Development. 4th Edn., Asian Institute for Public Health, Nakorn Pathom, ISBN: 9746393324, pp: 21-23.

2. Rithidet, P., P. Piampongsan, P. Prathepa and B. Yodmalee, 2005. The development of community economic system of thung kula ronghai farmers at Ban Ta Yuak, Northeastern Thailand. J. Soc. Sci., 1: 240-242. http://www.accessmylibrary.com/coms2/summary 0286-32150727_ITM.

3. Mibun, W., C. Vaddhanaphuti, S. Srisontisuk and C. Wittayapak, 2007. A story and belief in spirit of phoo (Grandpa) loop: An access to resources of fishermen at the Ubon Rattana Dam, Khon kaen, Thailand. J. Soc. Sci., 3: 172-175. http://www.scipub.org/fulltext/jss/jss34172-175.pdf.

4. Sati, P., J. Dhamawat, P. Pratepha and S. Rittidech, 2005. Changes in the conscious mind in applying technology for growing rice at the Chee River Basin in Northeastern of Thailand. J. Soc. Sci., 1: 172-177. http://www.scipub.org/fulltext/jss/jss13172-177.pdf.

5. Nartsupha, C., 2003. The Thai village economy in the past. J. Econ. History, 63: 265-266. DOI: 10.1017/S0022050703331808.

6. Akin Rabibhadana, 1970. The Organization of Thai Society in the Early Bangkok Period, 1782-1873. 1st Edn., Wisdom of The Land Foundation and Thai Association of Qualitative Researchers, Bangkok, ISBN: 10: 9748364798, pp: 304. 